\title{
Cultural and Intellectual Exchange between the Ottoman Egypt and the Rest of the Arab Muslim World in the Eighteenth - Early Nineteenth Century
}

\section{Svetlana Kirillina}

Professor of Islamic Studies Institute of Asian and African Studies Moscow State University, Russia

\section{unita}

تتحدث هذه المقالة عن تبادل الحضارة والثقافة التي حدثت بين مصر

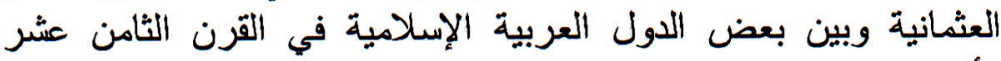

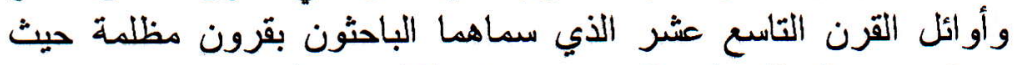

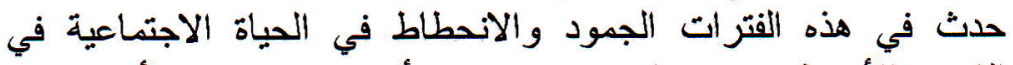

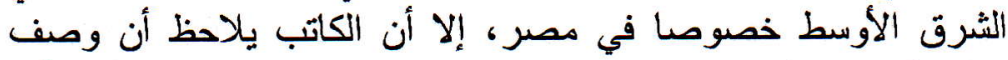

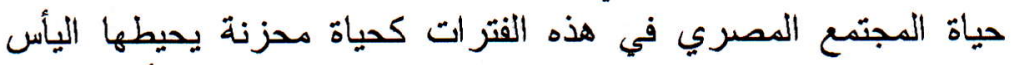

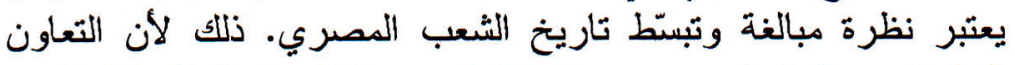

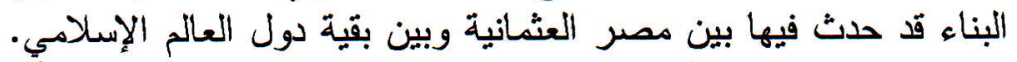

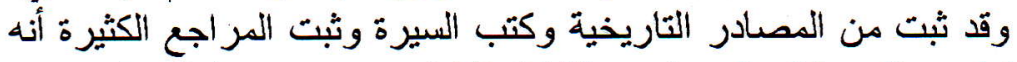

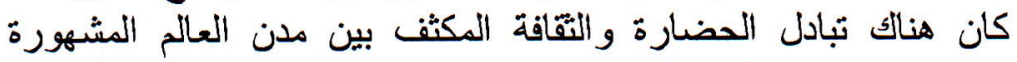

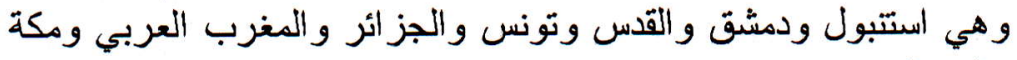
و المدينة ومصر •

\section{Abstrak}

Tulisan ini membahas tentang pertukaran kultur dan intelektual yang terjadi Mesir Usmani dan beberapa bagian dunia Muslim Arab pada abad ke -18 M- awal abad ke- 19 M, yang digambarkan oleh sebagian peneliti sebagai "Abad Kegelapan" di mana terjadi "stagnasi", "degradasi", dan "anabiosis" dalam kebidupaan sosial di Timur Tengah dan Mesir khususnya. Menurut penulisnya, penggambaran yang menyedibkan dan tanpa harapan tentang masyarakat Mesir itu dapat dianggap sebagai sesuatu yang berlebihan, atau suatu pendekatan yang terlalu menyerderhanakan persoalan tentang sejarah bangsa Mesir. 
Padahal, selama periode tersebut, telab terjadi bubungan yang intensif di antara Mesir Usmani dan dunia Muslim lainnya. Berlandaskan pada sumber data bistoris yang berupa kronik-kronik bangsa Mesir Usmani, didukung oleb ringkasan-ringkasan hagiografis dan bibliografis, dapat dibuktikan bahwa telab terjadi pertukaran kultural dan intelektual yang intensif di pusat-pusat pendidikan terkenal di Istanbul, Damaskus, Jerusalem, Tunisia, Algeria, Maroko, Mekkah, Madinab dan Mesir.

Keywords: history, cultural exchange, Ottoman Egypt, Muslim World.

This paper deals with cultural and intellectual exchange between the Ottoman Egypt and several substantial parts of the Arab Muslim world in the eighteenth - early nineteenth century.

Until quite recently the eighteenth century was portrayed in a number of researches as a lowest point in decline of the Middle East and Egypt in particular. This so-called "Dark Age" was considered to be a period of "stagnation", "degradation" and "anabiosis" of the social life and an era of the agony of Ottoman rule, when the Ottomans lost their last hopes to restore power in their largest Arab province. The "brutalizing" of the Ottoman order was sometimes going along with perception of the Islamic religion as a "doctrine of backwardness", which was spreading a notorious fanaticism and fatalism that held down human will and creative potential. These pessimistic conclusions pertained to economics, politics and cultural life. It was argued that isolation of Egypt in the Ottoman period caused its cultural and intellectual decadence. Emphasizing the stagnation of intellectual life in the Ottoman Egypt the well-known Egyptian scholar Jamāl el-Din sl-Shayyāl stated: "With the conquest of Egypt by the Ottomans Istanbul became the centre of gravity of the Muslim world. This fact may explain the deterioration of the intellectual life in Egypt during the Ottoman period, which lasted for three centuries... The isolation imposed on Egypt during the Ottoman period was largely responsible for the decline of cultural and economic life». ${ }^{1}$

\footnotetext{
${ }^{1}$ Gamal el-Din el-Shayyal, Some Aspects of Intellectual and Social Life in EighteenthCentury Egypt; Political and Social Change in Modern Egypt: Historical Studies from the Ottoman Conquest to the United Arab Republic, (London, 1968), p. 117.
} 
From my point of view, such statements should be regarded as a certain exaggeration, or, more precisely, as a simplified one-sided approach to the Egyptian history of the eighteenth century. This sad, hopeless picture of the Egyptian society, painted in gray and black colors could be adjusted. This would allow us for thinking over some stereotypes still existing in the Ottoman studies and questioning the argument about the lack of intensive connections between the Ottoman Egypt and the rest of Muslim world during the reviewed period.

At the very beginning I would like to point out that a bulk of my arguments and conclusions are based on rich historical data of OttomanEgyptian chronicles. First of all it is the most well-known chronicle 'Ajäib al-Athar fi-l Tarajim wa-l Akbbar (Marvelous History of the Past in Biographies and Description of Events) composed by the prominent Egyptian historiographer of the eighteenth - beginning of the nineteenth century Abd al-Rahmān al-Jabarti (David Ayalon called Jabarti "a giant among dwarfs"). Along with Jabarti's opus magnum quite well known local chronicles were used for the purpose of the research and among them Awdab al-Ishärat $\overline{f i}$ man tawalla Miss al-Qähira min alWurara', wa al-Bashat (Clear Indications and Elucidations in Respect to Those Vazirs and Pashas Who Ruled in Cairo) by Ahmad Shalabi ibn Abd alGhani and others.

Besides this kind of sources some of the most important hagiographical and bibliographical compendiums serve as verifying tools. They are Kitāb al-Yawäit ath-Thämina fi A'yän Madbhab 'Alim alMadina (Book of Gems, or Precious Stones in Biographies of Distinguished Scholars of Madbab of Alim from Medina) by Muhammad al-Azhar, Shajarăt an-Nur az-Zäkiya fi Tiabaqāt al-Malikiya ( $A$ Tree of Pure Light in Maliki Circles) by Muhammad Makhlūf and Silk ad-Durar fi A'yan alQarn al-Thani 'Ashr (Pearl Necklace of Notables of the Twelfth Century) by Muhammad Khalil al-Murādi.

The Arabic chronicles together with other sources contain the explicit evidence of intense migration within the Muslim World and particularly the Ottoman Empire where any internal barriers were absent. This migration intensified cultural and intellectual exchange between the well-known educational centers including famous madrasas of Istanbul, the Umayad Mosque of Damascus, madrasas al-Salihiya 
and al-'Uthmaniya in Jerusalem, al-Zaytūna in Tunis, the Great Mosque in Alger, college-mosques of the Moroccan imperial capitals - alKarayin of Fes, al-Kutubiya of Marrakech, large mosques of Meknes and Rabat, «the community of theologians» of the Holy Cities of Arabia - Mecca and Medina, and Egyptian high madrasas.

The most famous college-mosque al-Azhar was the major link in the wide and well-developed network of religious educational institutions in the Ottoman Egypt. There were 20 high madrasas and additionally about the same number of mosques with students' instruction by 'ulama' that functioned in Cairo. ${ }^{2}$ In addition to Cairo about 20 Egyptian towns had their own theological educational institutions, where the number of madrasas ranged from 1 to 7 . Alexandria, Damietta, Rosetta, Mansura, al-Mahalla, Fayyum, Dasuq, Tanta in the Lower Egypt and Qena, Qus, Tahta in the Upper Egypt had the most active network of madrasas. However, al-Azhar had the highest renomé, the most powerful financial support and attracted the greatest number of students.

Al-Azhar was created in the tenth century by Fatimids as a center of knowledge and propagation of the Ismaili doctrine. Later it was transformed into so to say Sunni "academy", which earned glory and prestige in all parts of dar al-IsTam. During the eighteenth century we could hardly find an Islamic educational institution capable to compete with al-Azhar. This college possessed the highest reputation of "the bearer of Islamic values and knowledge" and the "stronghold of Sunni Islam".

Al-Azhar trained theologians, jurists, teachers and other men of religious specialization for numerous Muslim countries. During the French expedition to Egypt Bonaparte could not help admiring alAzhar. He wrote that "it was the only institution capable to inspire the public opinion of the East and its four determining sects (madhäbib)". ${ }^{3}$ Al-Azhar was often described by different scholars as a blossoming

${ }^{2}$ Heyworth-Dunne, An Introduction to the History of Education in Modern Egypt, (London, 1938), P. 17-18

${ }^{3}$ Ibid. p. 19-23; H.A.R Gibb, H. Bowen, Islamic Society and the West Islamic Society in the Eighteenth Century. L., 1965. Vol. 1. Pt. 2, p. 155. 
oasis of higher Islamic learning (in the midst of desolation). According to the statement of the real connoisseur of al-Azhar's history, American researcher Bayard Dodge, "in spite of occasional quarrels, the old mosque kept spiritual and intellectual influences alive... As the eighteenth century came to a close, al-Azhar was undoubtedly the most important mosque and center of higher learning in Egypt". ${ }^{4}$ Al-Azhar professors were repeatedly depicted as "a community that was the best and most advanced of its kind during the Ottoman period". ${ }^{5}$ At the end of the eighteenth century al-Azhar taught three thousand students including one thousand from other Muslim regions. ${ }^{6}$ The organizational framework of Azhari students and teachers was a system of riwaqs, or sections arranged on the basis of birthplace, ethnic origin, association with one of the Sunni legal schools and a number of other factors.

A special group of riwäs, united students and teachers of nonEgyptian origin, who represented the wide geography of the Muslim World. The most ancient riwägs - al-Maghariba (North African), alShawnam (Syrian) and al-Atrak (Turkish) absorbed students from Tripoli (Libya), Morocco, Tunis and Algeria, al-Sham (the Greater Syria) and Turkey, including its European provinces. Other non-Egyptian riwäqs were comprised of Kurds, Indians, people from Iraq, Nubia, Sultanate Bornu and its neighborhood, Somali Coast, natives of the territories around the lake Chad, inhabitants of Mecca and Medina, students coming from Java, Khorasan, Afghanistan, South Arabia, etc. Al-Azhar riwa system also included one separate riwä for all nationalities together and two riwags for Hanbali and Hanafi schools, which were reserved for those students who did not have special riwaq for their place of origin. ${ }^{7}$

Compared to Istanbul, which was attractive for pragmatics who hoped to get promoted in their careers, high madrasas in Cairo - alAzhar University, college-mosques Sayidna Husayn, Sultan Hasan, al-

${ }^{4}$ Napoleon. Selected Works. Transl. into Russian, (Moscow, 1956), p. 472

${ }^{5}$ B. Dodge, Al-Azhar. A Millennium of Muslim Learning, (Washington, 1974), p. 91

${ }^{6}$ Raymond A. Artisans et Commerçants au Caire au XVIIIe siècle. T.1-2. Damascus, 1973-1974, p. 420

7 'Abdallah Muhammad 'Annan, Târikh Jāmi' al-Azhar, (Cairo, 1958), p. $300-$ 305; Heyworth-Dunne, An Introduction... p. 25-27. 
Jawhariya, al-Muhammadiya, al-Ashrafiya, etc., attracted those who "strove for knowledge" (talab al-ilm). Several "noble" families, who were firmly established in their home regions, were traditionally sending their sons to al-Azhar. The vivid example of this tendency is the famous Abu Lutf (Jarallah) family from Jerusalem, which had at least ten members educated in Cairo. ${ }^{8}$

Prestigious Azhari education enabled those who studied in Cairo to attain high offices in the religious hierarchy, to become mufti, qa $\bar{a} \bar{i}$ or teach in most renowned local madrasas. If a certain family "monopolized" a concrete position connected to religious sphere, which was typical for Syria, Anatolia and other Eastern parts of the Ottoman Empire, the Azhari education served as a certain guarantee for keeping this post in the hands of this family.

The newcomers easily integrated to and felt themselves comfortable in Cairo "intellectual community" as they were surrounded by many compatriots. At the end of the eighteenth beginning of the nineteenth century Cairo served as a residence for large communities of non-Egyptians who arrived there from the other Ottoman provinces and Muslim countries.

Professor André Raymond estimated the so-called "foreign" population of Cairo during the eighteenth century to have been about $10 \%$ of the total, including 10 thousand Turks, 10 thousand Maghribis (mostly Moroccans and Tunisians) and 5 thousand Syrian Muslims. Each non-Egyptian Muslim community was headed by shaykh, who could be an 'alim practicing in al-Azhar, as it often happened in the Maghribi community. The majority of young people who came to Egypt from other Muslim regions preferred to return back home after the completion of their studies. At the same time there were plenty of

${ }^{8}$ U.M.Kupferschmidt, Connections of the Palestinian Ulama'-' with Egypt and Other Parts of the Ottoman Empire; Egypt and Palestine. A Millennium of Association (868-1948). Jerusalem; (New York, 1984), p. 182-183.

${ }^{9}$ A. Raymond, „Le Caire sous les Ottomanes (1517-1798)” in B. Maury, A. Raymon J., Revault and M. Zakariya (eds), Palais et maisons du Caire. Vol. 2. Époque Ottomane (XVI-e - XVIII-e siècles), 1983, p. 28, 35-36; Raymond, André. «L'Impact de la pénétration europeenne sur l'économie de l'Égypte au XVIII-e siècle.» Annales Islamologiques (le Caire), vol. 18, 1982, p. 221. 
those who settled in Egypt and established themselves in the local religious elite. 'Ulamā' from Maghrib were the most active among them. They participated in social and cultural activities of al-Azhar and other madrasas and from time to time reached high religious positions. Some of them succeeded in building up a wide network among the OttomanMamluk officials and were very successful in setting up friendly relations with the representatives of the top political and military circles.

The Egyptian historiographer Ahmad Shalabi mentioned shaykh Muhammad al-Saghir al-Balta' un from Maghrib (d. 1726), who became extremely famous in al-Azhar for his deep knowledge of one of the most difficult and refined theological disciplines - tawhid. ${ }^{10}$ According to al-Jabarti, Sayyid 'Umar ibn 'Ali al-Fattūshi, known as Ibn al-Wakil (d. 1762) came to Cairo in the early forties of the eighteenth century and began to study books of hadith. He showed himself as a skillful poet and also became an overseer of the courts in one of Cairo districts (Kamiliya District). ${ }^{11}$

According to al-Jabarti, a distinguished shaykh Muhammad ibn Hasan al-Jazä'iri (d. 1773) was brought to Cairo by his father - Algerian merchant. The young clever boy became closely attached to the Hanafi mufti Hasan al-Makdisi, who taught him judicial subjects. Soon Muhammad started to assist his master in classes and even wrote on the fatwas. After the death of his mentor, Muhammad al-Jazä'iri began to teach his courses and quickly became well-known and honored person. ${ }^{12}$

Shaykh Abū-l-‘Abbas al-Jazā'iri al-Maghribi (d.1788) was born in Algerian Sahara. He was brought to Cairo in his childhood and educated in al-Azhar in different theological disciplines. Afterwards he began to lecture in the Maghribi riwaq combining teaching with the

${ }^{10}$ Ahmad Shalabi ibn 'Abd al-Ghani, Awdah, al-Ishärät fi man tawallā Misr alQähira min al-Wuzara's' wa al-Bashat. Edited and annotated by 'Abd al-Rahim 'Abd alRahman 'Abd al-Rahim, (Cairo: Maktabat al-Khanji, 1978), p. 488-489

11 'Abd al-Rahmman ibn Hasan al-Jabarț 'Ajaib al-Athär fi al-Tarajim wa al-Akbbar, Vol. 1-4. Bulak, 1879-1880. Vol. 1, p. 262; Al-Jabarta, History of Egypt. ( 3 books, vol. 14). Stuttgart, 1994. Vol. 1.p. 433

${ }^{12} \mathrm{Al}-\mathrm{Jabarti}$, ibid, Vol.1. P. 379; Al-Jabarti, History of Egypt, Vol. 1.p. 636; 'Abd al-Rahim 'Abd al-Rahman, Al-Maghariba fí Masr fi al-'Asral-Uthmani (1517-1798), Tunis, 1982. N. 104 
duties of inspector of madrasa al-Jawhariya. He was widely recognized for eloquence and excellent memory. ${ }^{13}$

Another Maghribi by birth, the famous jurist and philosopher Abu-l-Hasan al-Qadi ibn 'Ali al-Maghribi (d. 1875) arrived in Cairo in 1741/42 and became the mentor of the Ottoman wali of Egypt, Muhammad Pasha Raghib. When Raghib Pasha received a post of great wazi $\bar{i}$, he continued to take care of his teacher and granted him the monthly pension at the expense of the Egyptian mint. Shaykh Abu-lHasan al-Qādi occupied a prestigious post of the head of the Maghribi riwa $\bar{q}$ several times and, according to the statement of Muhammad Makhlüf, executed his duties "with a keen insight, strictness and severity». ${ }^{14}$ As al-Jabartî marked, he "gained high respect, became very influential and was considered to be one of the highest-ranked shaykhs ${ }^{15}$ Among the heads of the Maghribi riwa'q, listed in al-Jabarti's 'Ajaib, biographical dictionaries of Muhammad al-Azhari and Muhammad Makhluf, we could easily find distinguished leaders of the Azhari Maghribi community, learned shayks from Morocco Tunis and Libya.

Cairo welcomed many 'ulamā' from the Greater Syria, Arabia and Iraq. Some of them made successful careers in Egypt in spite of the fact that newcomers were normally not as quickly promoted as local inhabitants. As an example I would like mention shaykh 'Ali ibn Mūsā al-Husayni (1713-1772), ${ }^{16}$ the native of Palestine. He was known as Ibn an-Naqib because his famous ancestors served as heads of descendants of the Prophet Muhammad (singular naqib al-ashraf) in Jerusalem. As Muhammad Khalil al-Murādi and al-Jabarti mentioned, shaykh 'Ali Ibn an-Naqib studied in al-Azhar and afterwards taught the exegesis of the Quran, tafsir, Islamic law, $\operatorname{shari}^{\bar{\tau}} a$ and badith at the Husayni Shrine combining the basic professional occupation with fi Mast, p. 105.

${ }^{13}$ Al-Jabarti, 'Ajaib. Vol. 2. p. 167. 'Abd al-Rahim 'Abd al-Raḥman, Al-Maghariba

${ }^{14}$ Muḥammad ben Muḥammad Makhlūf, Shajara al-Nür al-Zakija fĭ Ṭabaqāt alMalakiya, Beyrut, [s.a.]. P. 343, No. 1356. (указать место издания)

${ }^{15} \mathrm{Ibid}, 65$.

${ }^{16} \mathrm{Ibid}, 87$. 
seemingly extravagant hobby for a man of his specialization, namely study of the genealogy of pure-bred horses. He was an excellent horserider, expert in arrow shooting, use of arms and games of lances.

Shaykh 'Ali Ibn an-Naqib was well known for his extraordinary generosity and hospitality. According to al-Jabarti, "whatever he obtained of worldly goods he would turn over to those who needed assistance. His home near the Husayni Shrine was a station for petitioners and visitors». ${ }^{17}$ Sometimes he attacked the rich and the powerful imputing to them injustice, violence and deviation from the true path. Burdened by debts and prosecuted by authorities he moved to Istanbul. After returning to Cairo shaykh 'Ali continued his charity actions and remained hospitable to guests. Towards the end of his life, when he was in distress, he asked the leading mamluke of that time amir Muhammad Bey Abū al-Dhahab for financial assistance and received from him a substantial amount of money (100,000 paras). With this money the shaykh paid some of his debts, and spent the rest on the poor.

It is possible to assume, that, besides shaykh 'Alis sympathy to the needy and poor, he was also guided by more prosaic motive, namely, creating a big group of supporters who served as a guarantee for his wide publicity. Feeding his followers, 'Ali Ibn al-Naqib fully exhausted his financial resources but retained the people's admiration.

Another representative of the noble sharifi family from Jerusalem Husayn ibn Sharaf al-Din al-Thawri (d. 1780) spent a long period of his life in Cairo. He settled in the Syrian riwä and studied under the guidance of the prominent Azhari shaykhs. He became a notable figure in the high spiritual and political circles and the close aid of Muhammad Abu'l-Hadi al-Sadat, naqib al-ashraf, or the head of the Egyptian descendants of the Prophet Muhammad (ashraf). After the death of his high-ranked patron, shaykh Husayn al-Thawri moved to Istanbul, where he was accepted as an "equal among nobles". ${ }^{18}$

${ }^{17}$ Muhammad al-Bashir Zafir Al-Azhari, Kitāb al-Thämina fĭ A'yān Madhab 'Alim al-Madina, [s.1.], 1096/07. p. 197-198; Makhlüf, Shajarät al-Nür al-Zäkiya, p. 342, №. 1354 (проверить правописание)

${ }^{18}$ Al-Jabarti, 'Ajaib, Vol. 3. p. 114 
Shaykh Zayn ad-Din Abū Ma'ali al-Makki (1729/30-1763) was born and grew up in Mecca. However, it was in Cairo, where he moved and spent the rest of the life and where his bright talent for poetic improvisations flourished. Along with the basic works of the theological contents he composed numerous poems, one of which was devoted to the history of the Egyptian capital. ${ }^{19}$

The imam, Sufi and ascetic Muhammad Sacid ibn Abi Bakr alHusayni al-Baghdadi (d. 1767) from Iraq came to Cairo in $1757 / 58$. He traveled through Arabia and Turkey, working saintly miracles. As the annals said, "his fame spread, and he attracted followers and disciples". ${ }^{20}$

Close connections with the native places were kept by such outstanding 'ulama' as 'Abd al-Rahman al-'Aydarus (d. 1778) from Tarim in Khadramayt or Muhammad Murtadā az-Zābidi (d. 1791) from Bilgram (Northern India), although both scholars felt themselves very homelike in Egypt. ${ }^{21}$ Murtadā al-Zabidi and his diverce and numerous writings became an object of profound research conducted by German professor Stephan Reichmuth, who produced several superb articles on this issue.

According to Reichmuth, Murtada az-Zābidi, as a leading figure of Islamic scholarship of his days, made a lasting impact on Arabic and Islamic learning and prepared a ground for the Arabic literary revival in the nineteenth century. His role as an important bridging point for different local networks of Islamic scholarship and authority in the late eighteenth century was strikingly remarkable. Az-Zäbidi's lasting reputation was built on his famous dictionary the Taj al- 'Arūs, the largest dictionary ever compiled in the classical tradition of Arab lexicography.

Az-Zäbidi settled in Egypt when he was still quite young it was in Cairo that he established his fame among his contemporaries. Az-

${ }^{19}$ Al-Jabartă, 'Ajaib, Vol.1. p. 371-373; Àl-Jabarti, History of Egypt, Vol. 1. p. 624627; Muhammad Khatil al-Murādi, Silk al-Durar fí A'yān al-Qarn al-Thäni' Ashar. Vol. 14. Bulaq, 1301/1883/84. Vol. 3. p. 246

${ }^{20}$ Al-Jabarti, 'Ajaib, Vol.1. p. 372; Àl-Jabarți, History of Egypt, Vol. 1. p. 625

${ }^{21}$ Ibid, Vol. 2. p. 70-71. 
Zäbidi attracted scholars, students and pilgrims from all over the Islamic world and many of his visitors regarded him as a religious figure of high spiritual rank. Consequently, a new pattern of far-reaching religious connections emerged from his activities.

A close analysis of Zäbidi's life and work allowed Prof. Reichmuth to state that Zäbidi's wide travels and his network of religious and scholarly contacts as well as his contacts with many different local elites even far beyond the frontiers of the Ottoman Empire served as a vivid proof to one of the crucial developments of the period under review, mainly the growing interconnection and standardization of Islamic culture and scholarship, a high mobility of scholars and a remarkable wide range of local educational activities in the eighteenth century.

In spite of the fact that the Turkish community in Egypt was the most numerous, Egyptian-Ottoman narrative sources do not often mention Turkish 'ulamä', who made a valuable contribution to the religious and intellectual life of the Egyptian province. It is hardly possible to assume that local historians, guided by some special subjective reasons deliberately excluded the information about Turkish 'ulama' from their annals. For example, al-Jabarti did not forget to mention Turks of certain public importance. However, we should not close the problem of the Turkish spiritual impact on the Egyptian Muslim community and agree with those scholars, who proclaimed that Ottomans didn't possess the "sufficient civilizing capital", which they could "invest" into the intellectual life of Egypt. ${ }^{22}$

This topic could be analyzed from the different prospective, having in mind the statement of the French scholar Pobert Mantran, who emphasized the importance of al-Azhar for maintenance of the prestige of the Ottoman state and pointed the significance of the bajj as a channel for Turkish pilgrims visiting Egypt and strengthening Egyptian-Turkish relations in the intellectual and religious sphere. ${ }^{23}$ As I mentioned above, my research is based mainly on the Arabic 432-433.

${ }^{22}$ Al-Jabarti, 'Ajä'ib. Vol.1. p. 261-262; Àl-Jabarti, History of Egypt, Vol. 1. p. ${ }^{23}$ 'Ajaib, Vol.1. p. 285; History of Egypt, Vol. 1. p. 473 
sources and therefore the same issues need to be studied analyzing the information contained in Turkish sources.

The prominent 'ulama' of Maghrib, Mashriq and other Islamic regions whose lives were closely tied to Egypt were known for broadness of their academic interests. They were involved in researches in different fields including Muslim theology and law, literature, linguistics, mathematics, astronomy, medicine, natural sciences, history and other scientific fields.

The present author would like to avoid the discussion of the specific features of Egyptian intellectual tradition in the Ottoman period and the quality of the Arabic theological literature of the eighteenth century, which supposed to be marked by the signs of degradation. This debate, traced back to scholars like Hamilton Gibb, Albert Hourani and Fazlur Rahman, has now increasingly focused on the controversial notion of "Islamic Enlightenment". This complicated multi-sided problem deserves to be a subject of separate lecture and further research. You can consult, for instance, numerous publications on this important subject produced by two German scholars Reinchard Schulze and Bernd Radtke who contributed to a considerable extent to this long-lasting polemics. I would like just to mention that a comprehensive panorama of intellectual life in nineteenth century Asia and Africa is still far from satisfactory reconstruction. It seems that the main obstacle, barring the way for such a reconstruction, is a strong influence of heritage of the European colonial scholarship - I mean both its interpretations of facts and conclusions.

If we examine briefly main features of one and the same quite stereotyped image of Islamic intellectual tradition as they are seen in the early European historiography, we will come to the conclusion that Arab-Muslim intellectual milieu could only be characterized by stagnation of minds and backwardness of knowledge and could produce nothing but narrow-minded scribes affected to a considerable extent by xenophobia. Conclusions of this kind concerning traditional learning were and still are often projected on literary heritage of Muslim intellectuals.

A taste for compilation, so characteristic of 'ulamä', as well as their manner to imitate the patterns of medieval genres was considered 
in the so-called "colonial" historiography as an obvious sign of decline of culture of writing or as an evidence of futility of spiritual erudition. Long standing tradition of commenting medieval treatises, which was so widespread among Muslim intellectuals, was also condemned as a source of narrow scholasticism.

In the meantime study of narrative evidence of intellectual life in the Ottoman Egypt and other parts of the Arab-Muslim world in Arabic sources and European travelogues allows us to talk about diversity of forms of intellectual and spiritual activities as well as their obvious popularity in urban society. It seems that two levels of intellectual exchange may be marked out: one - more popular, and other - typical for higher social strata.

The first of them was manifested in public gatherings, which were usually timed to collective prayer on Friday, celebration of Prophet's anniversary (maulid) or holy month of Ramadan. They were held in mosques or Sufi lodges - zawiyas and takiyas. During these gatherings local or visiting connoisseurs of traditional Islamic disciplines delivered lectures for all comers. The audience of such lectures was often numerous and this tradition was deeply rooted. Here we ought to put a question: to what extent did the intellectuals contribute to creation of spiritual atmosphere of the city?

On the one hand, the audience was formed by chance and its erudition varied; so, the orators were forced to a certain extent to choose topics related to everyday life, operate by graspable notions and use simplified, so to say, popular language. On the other hand, such «public lectures» allowed Muslim erudite to transmit ideas of the learned circles among common people, though in simplified form. Doing this, traditional intellectuals tried to overcome inevitable conflict of «high» cultivated tradition of few thinking minds and «populan wild-growing spiritual values of many commoners. In the meantime, when giving to the crowd moral orientations and guiding social behavior of the audience, they did not only fulfill their enlightening mission, but also improved their social status.

The second, higher level of intellectual exchange was manifested in private scholarly gatherings, which were very typical for traditional way of life in Muslim cities in the eighteenth - beginning of the 
nineteenth century. They were held in houses of 'ulama', mamluks, Ottoman officials, and even merchants and artisans. In most cases problems of spiritual nature served to the participants as subject of discussion. However, we should not come to the conclusion that topics of private gatherings were strictly limited to religious matters. Undoubtedly, the universal nature of Islamic dogmas allowed examining any problem from spiritual point of view.

In numerous biographies of the shaykhs-Malikits, included by Muhammad Makhlūf in his biographical compendium (Shajara al-Nür al-Zakiya fi Trabaqāt al-Malakiya), Muhammad al-Bulaydi al-Maliki alAndalusi (d. 1763) of sharifi-Maghribi origin is often mentioned as a person greatly honored for being a brilliant teacher of dozens of 'ulama'. He was especially admired by the Maghribi merchants because of common ethnic origin. They gave shaykh Muhammad presents and donations and shared the price of the house that they bought for him. ${ }^{24}$

Muhammad Makhlūf and 'Abd al-Rahman al-Jabarti wrote about the honorable shaykh Muhammad al-Sanbawi al-Amir (1741-1817), whose Algerian ancestors settled in the Nile Valley and became multazims $5^{25}$ Shaykh al-Amir succeeded in many disciplines - kalam, tafsir, cosmogony, geometry, astronomy, falsafa, medicine, etc., and gained "a tremendous glory, particularly in Maghrib" ${ }^{26}$ The Moroccan Sultan, having learned about his virtues, sent students to Cairo to study under his guidance and presented him generous gifts every year. ${ }^{27}$

The number of 'ulama' of non-Egyptian origin who settled in Egypt was quite small. Gabriel Baer found only five biographies of 328-329

${ }^{24}$ Al-Jabartī, 'Ajäìb, Vol. 2. 196-210; 27-34; al-Murādi, Silk al-Durar, Vol. 2. p.

${ }^{25}$ Iltizam (pl. iltizamat) means a rural tax farm, or estate and multazim - a holder of iltizam, or a tax farmer who collected t axes from peasantry and paid a part of the taxes which was called miri to the State treasury. The remaining portion of taxes called faizwas regarded as the multazim's share. It was kept by multazim and usually exceeded a half of the collected sums. It means that the bulk of the landed revenue of Egypt went not to the state but to multazims, or tax farmers.

${ }^{26}$ Muḥammad Anis, Tarikh al-Mișrifí al-'Asr al-Uthmāni, Cairo, 1962. p. 14

${ }^{27}$ R. Mantran, Les relations entre le Caire et Istanbul durant la periode Ottomane: Colloque International sur l'Histoire du Caire, 27 mars - 5 avril 1969 (Cairo), Grafenhainchen (DDR), 1972. p. 302 
the 'ulama' from Jeruslaem in al-Jabarti's chronicle. Only three of these "immigrant notables" lived in Cairo in the eighteenth century. ${ }^{28}$ The estimates by Uri M. Kupfercshmidt, based on the Palestinian historical data, were equally modest (though the author emphasized the incompleteness of data). In the eighteenth century 24 persons from Palestine received their higher religious education in Cairo (twelve were from Jerusalem, seven from Nablus, two from Jaffa and three from Gazza). Only three out of those 24 who came from Jerusalem moved permanently to the Egyptian capital. ${ }^{29}$ However, the quantitative characteristics can not serve as a valid representation of the essence of the intellectual exchange. The active correspondence, mutual visits and exchanges of manuscripts (and ijazas, etc.) served as a bright evidence of the connections between different Muslim regions.

Let's recollect, that in accordance with one of the hypotheses it was the activities of the famous historian from Damascus shaykh Muhammad al-Murāi that inspired 'Abd al-Rahmān al-Jabartỉ to write his outstanding chronicle 'Ajäib al-Athar fill-Tarajim wa'-Akbbär (Marvelous History of the Past in Biographies and Description of Events)..$^{30}$ Al-Murādi corresponded in a large scale with eminent scholars of the Arab-Muslim World and urged them to collect biographies of the noble men and to record the events of the twelfth century (1688/9-1784/5).

The shaykh Ahmad ibn 'Abdallah al-Susi (d. 1779), whose glory "spread all over the African countries", 31 never left his native Tunis. However, his impressive collection of manuscripts constantly grew due to a good relationship with the Azhari 'ulama $\bar{a}$, especially with Muhammad al-Murtada, who sent him a large number of books each year based on the list he received. At that time rich libraries of certain renowned Egyptian theologians were continuously enlarged by gifts of rare books sent to them by their colleagues-'ulamä, Ottoman and Moroccan Sultans, high-ranked officials of Istanbul and pashas of

${ }^{28}$ Al-Jabarti, 'Ajä'ib, Vol.1. p. 259; Al-Jabart̄, History of Egypt, Vol. 1. p. 429

${ }^{29}$ Makhlüf, Shajarät al-Nür al-Zäkija, p. 362-363, № 1446; Al-Jabart̄i, 'Ajäìb, Vol. 4. p. $284-285$.

${ }^{30}$ Makhlūf, ibid, p. 363

${ }^{31}$ Jerusalem G. Baer, Notables in Ottoman Cairo, Egypt and Palestine. A Millennium of Association (868-1948), (Jerusalem; N.Y.), 1984. pp. 167-175 
Tunisia and Algeria.

The correspondence between Hanafi mufti of Jerusalem Tahir Afandi al-Husayni and outstanding Egyptian 'ulama', - the historian 'Abd al-Rahmān al-Jabarti and two rectors of al-Azhar - 'Abdallah alSharqawi and Hasan al-'Attār illustrates the cultural ties between Cairo and Jerusalem in the early nineteenth century. The contents of these letters, analyzed by the Israeli scholar 'Adel Manna', confirm the significance of Cairo not only as an accumulator of sanctuaries attracting thousands of pilgrims, but also as an important reservoir of cultural information and an alternative starting place for building careers. ${ }^{32}$

Jerusalem could not compete with Cairo in fame and popularity of educational institutions. However, its importance as a second after baramaya (Mecca and Medina) pilgrimage center for Muslims from all over the world was indisputable. "Cairo and Jerusalem, - emphasizes the Israeli scholar 'Adel Manna', - preserved cultural ties, which were conducted through the 'ulama' ... In addition to the geographical proximity, status and role of al-Azhar, social and economic factors also contributed to the preservation of these ties even three centuries after Jerusalem had ceased to be ruled from Cairo." ${ }^{\text {33 }}$

The similar positive idea concerning Maghrib was expressed by André Raymond. He wrote that "the influence of the East and, to be more precise, of the intellectual community of Cairo, exerted through the pilgrimage channel and al-Azhar, significantly determined the fate of Maghrib».34 Egypt became a temporary shelter for many 'ulamä, who were inspired by the muse of wanderings. Egyptian madrasas hosted many Muslim scholars from the most remote parts of dar alIsläm.

In reference to this we can list several episodes from the life of an illustrious Tunisian theologian Muhammad Zaytūna al-Sharif alManastiri (d. 1725), as they were described by Muhammad Makhluf.

${ }^{32}$ Kupferschmidt, Connections of the Palestinian Ulamä' p. 179, 189

${ }^{33}$ Details see Al-Jabarti, 'Ajaib, Vol.2. p. 360-365; D. Ayalon, "The Historian alJabarti and his Background" in Bulletin of the School of Oriental and African Studies, vol. 23, pt. 2, 1960. p. 224-227

${ }^{34}$ Al-Jabarti, 'Ajaib, Vol. 2. p. 57 (his biography see ibid, p. 56-57 
Shaykh Muhammad al-Manastiri went on a pilgrimage to Mecca twice - in 1702/3 and 1712/3 and each time he stopped for a long period in Alexandria and Cairo, where local 'ulama', appreciated his bright knowledge and merits by giving him ijazas. ${ }^{35}$

The present author would like to mention in this respect an outstanding Magribi hadith expert and knowledgeable jurisprudent of the Spanish descent Abū 'Abdallah Muhammad ibn Suda al-Fasi alTawudi (d. 1795). Muhammad Makhluf called him respectfully "the moon of Maghrib" ${ }^{36}$ Al-Jabarti recorded this 'alim's detailed biography, where he reckoned him to be among "the most outstanding personalities of his time", who left good memories of himself among Cairene "servants of Allah"."

While travelling through the Arab East, Ibn Suda visited al-Azhar several times and once spent a year there, giving lectures on jurisprudence. Open classes of the Moroccan scholar, organized in the Maghribi riwaq during his visits to Cairo on his way to the Holy Cities of Arabia and back (in 1767/8 and 1769/70), were attended by crowds of people including "the majority of the [Egyptian] 'ulama'. ${ }^{38}$ In his homeland shaykh Ibn Suda carried out duties of mufti and after the death of the Moroccan Sultan Sidi Muhammad, when a severe political crisis burst out, he supported Mulay Sulaymā (r. Morocco 17901822) in his successful fight for the Moroccan throne.

Egyptians welcomed hospitably the skillful Koran reciter and badith expert from Medina 'Abd al-Qädir ibn Khalil al-Madani, known as Gedikzada (d. 1773 in Nablus). The routs of his journeys always led to the recognized centers of Muslim learning - Istanbul, Tarbulus al-Sham, San'a', Jerusalem. He appeared in Cairo first as a diligent pupil, and afterwards as a distinguished scholar. In the course of his trips shaykh 'Abd al-Qa'dir went to the Upper Egypt and established

35 'Adel Manna', "Cultural Relations between Egyptian and Jerusalem 'Ulamā' in the Early Nineteenth Century" in Studies in Islamic Society: Contributions in Memory of Gabriel Baer, (Haifa, 1984), p. 139-149.

${ }^{36}$ Ibid, p. 149

${ }^{37}$ A. Raymond, Les vébicules: le pèlerinage et le mouvement commercial entre le Maghréb et l'Égypte; Les Cabiers de Tunisie, tome 7, 1959. p. 371.

${ }^{38}$ Makhlūf, Shajarāt al-Nūr al-Zäkiya, p. 324-324, № 1267. 
friendly relations with chiefs of the Hawwara Bedouin tribe, who appreciated him for masterful odes, composed by the 'alim in their honor. ${ }^{39}$

Muslim pilgrimage played a significant role in the intensification of cultural contacts. Thousands of pilgrims from Maghrib, central areas and the east coast of Africa, from islands of Zanzibar and Madagascar concentrated in Cairo before leaving for the Holy Lands of Arabia. In the eighteenth century the Egyptian pilgrimage caravan amounted from thirty to forty thousand people including pilgrims from Maghrib and other African regions. ${ }^{40}$

Many 'ulama' preferred to arrive to Egypt a year before the planned bajj. They joined the communities of scholars in al-Azhar or other high madrasas, delivered lectures, organized theological disputes with their colleagues, (exchanged ijazas), searched for rare manuscripts and visited sacred tombs and numerous mosques.

As there was a constant flow of students and teachers from many parts of the Muslim World to Egypt and since many pilgrims and merchants traveled outside Egypt, local 'ulama' were well aware of new ideological trends in various Islamic regions. The Egyptian "men of pen" were well informed about such important events as the Wahhabi movement in Arabia or reformatory undertakings of the Moroccan Sultan Mulay Sulayman. ${ }^{41}$ Egyptians ('ulamä' as well as others) were generally reluctant to travel abroad and usually preferred to leave their native land only during the pilgrimage. ${ }^{42}$ However, having been recognized as highly educated men at home, some of them made a decision to travel with an intellectual purpose.

${ }^{39}$ Al-Jabarti, 'Ajä'ib, Vol. 2. p. 244 (the biography see ibid, p. 242-244).

${ }^{40} \mathrm{~J}$. Jomier, Le machmal et la caravane égyptienne des pèlerins de la Mecque (XIII-e XX-e siècles), Caire, 1953. p. 135; Histoire de l'Empire Ottoman, (France, 1989/90), p. 371; J.-J Brégeon, L'Égypte française au jour le jour 1798-1801, (Paris, 1991), p. 36

${ }^{41}$ См.: Васильев А.М. История Саудовской Аравии (1745-1973). М., 1982. ОрловВ.В. Крах ваххабитской модели в Магрибе: реформы марокканского султана Мулай Слимана (1792-1822 гг.) // Вестн. Моск. ун-та. Сер.13. Востоковедение. № 4, 1993

${ }^{42}$ B.Dodge, Al-Azhar... p. 92; M. Winter, Egyptian Society under Ottoman Rule, 1517-1798, (London, 1992), p. 117, 140 
The journeys throughout Ottoman lands played a decisive role in the intellectual development of the rector of al-Azhar Hasan al'Attar (d. 1834 or 1835) and his formation as a scholar with the remarkably diverse academic interests. He spent ten years outside Egypt, lived for a long time in Rumelia and Istanbul, visited Izmir and Damascus, traveled through Palestine and finished his wanderings with bajj to Hijaz. Hassan al-'Attar pursued his studying and writing books on Arabic grammar, linguistics and natural sciences throughout his life. However, during his trips and after his return to Egypt Hassan al'Attar's scholarly work was complemented by writings on kalam, philosophy, logic, medicine, etc. ${ }^{43}$

At that time bright intelligence and academic achievements were highly appreciated in dar al-Islam. (As a Moroccan professor M'Hammad Benaboud correctly noted,) "Being a scholar was like having a passport enabling its holder to receive the recognition of intellectuals and other members of society in the most remote areas of the Ottoman state." ${ }^{\prime 4}$

The Holy Muslim Cities Mecca and Medina, which could be called were called by a British author David Waines "a microcosm of the ummah"45, played the role of major cosmopolitan centers, where scholars from every corner of the Muslim World came to live, often for lengthy periods. They studied or taught religious sciences and exchanged ideas before returning back home.

The dynamic cosmopolitan haramayn community of men of the "spiritual specialization" was constantly on the move and never took fixed forms. Many key figures within Egyptian 'ulama' group spent time in the Holy Lands of Islam and became an important part of the baramayn community. Some of them left Hijaz just after performing the obligatory pilgrimage rituals and short meetings with colleagues, others settled there for longer and deepened their knowledge of different subjects, improving professional skills as instructors of the younger generation.

${ }^{43}$ F. de Jong, "The Itinerary of Hasan al-Attar (1766-1835): A Reconsideration and its Implications" in Journal of Semitic Studies, vol. 28, № 1, 1983. p. 99-128

${ }^{44}$ Hammad Benaboud, Authority and Power in the Ottoman State in the Eighteenth Century: Decision Making and Change in the Ottoman Empire, (Kirksville, 1993), p. 73.

${ }^{45}$ D. Waines, An Introduction to Islam, Cambridge, 1950. p. 204 
The large urban centers - Cairo, Damascus and Zabid served as gateways to the heartland of Islam. These cities together with haramayn formed, according to Nehemia Levtzion and John O.Voll, "an inner circle of the Muslim world, where significant intellectual interchange took place." ${ }^{\prime 46}$

The Ottoman-Egyptian chronicles often mention the contribution of the Egyptian notable scholars to this productive intellectual dialogue. For instance Shaykh Ahmad ibn 'Abd al-Fattah al-Malawi (1677-1767) left to baramayn in his middle age. He studied there under the guidance of brilliant teachers and returned to Cairo "as an outstanding scholar of his day, one, to whom difficult questions were referred... Class after class and generation after generation, the students benefited from his teachings." ${ }^{\prime 37}$

A famous scholar of fiqh and badith, who delivered fatwas for nearly 60 years, shaykh Ahmad al-Khalidi al-Jawhari (d. 1768) undertook several trips to the Two Holy Cities. During these journeys he was taught by the most advanced and profound scholars and acquired great knowledge. Towards the end of his life shaykh Ahmad al-Jawhari, his family and dependants moved to baramayn, where he gave lectures for the benefit of all who attended. ${ }^{48}$

The episode from the biography of a gifted and eloquent Cairene imam 'Uthman ibn Muhammad al-Shimi, which we find in 'Ajaib seems very typical in this respect. «Having made the pilgrimage to the Prophet's grave, - witnesses al-Jabarti, - he settled in Medina; in one year his family also moved there. He sold all his belongings and fully dedicated himself to pious deeds, attended classes on hadith and Muslim law... The inhabitants of Medina loved him. He got married and children were born, then he married for the second time. So he lived until his death, which happened this year (1795/6)" ${ }^{49}$

\footnotetext{
${ }^{46}$ N Levtzion \& J.O. Voll, (ed.), Eighteenth-Century Renewal and Reform in Islam, Syracuse; (New York, 1987), p. 8. 476

${ }^{47}$ Al-Jabarti, 'Ajaib, Vol. 1. p. 286-287; Al-Jabarti, History of Egypt, Vol. 1. p. 475 -

${ }^{48}$ Ibid, Vol.1. p. 310-311; Al-Jabarti, History of Egypt, Vol. 1. p. 515-519

${ }^{49} \mathrm{Ibid}$, Vol. 2. p. 263
} 
The stay in Mecca and Medina was considered to be the most important event of 'ulam $\bar{a}$ ' 's life and in many respects predetermined their immense prestige in the eyes of their contemporaries seeking for blessings of outstanding bajj (those who have performed the pilgrimage to Mecca).

Muhammad ibn Ahmad al-Khälidi al-Jawharì (1738-1800/01), a man of illustrious intellect, whose fame spread far beyond the borders of Egypt, performed the baij three times and twice lived in Mecca for a year. There he successfully taught, collected rare books and wrote works on theological, judicial and linguistic subjects. In Egypt shaykh Muhammad al-Jawhari was involved in the major events of the religious life, and his wide popularity as a scholar and indisputable authority of baij reinforced his position among the most influential members of the local religious elite. Two rectors of al-Azhar (Ahmad al-Arusi and 'Abdallah al-Sharqawi) were appointed to this high religious post thanks to his active support. ${ }^{50}$

It is important to mention here that at the beginning of the eighteenth century the majority of badith transmitters and experts on Islamic tradition in the Holy Cities were pupils or followers of the prominent Egyptian mubaddith of the seventeenth century Muhammad ibn 'Ala' al-Din al-Babili (d.1666). An impressive list of their names can be found in al-Jabarti's chronicle. ${ }^{51}$

The interaction between resident 'ulama' and visiting scholars did not create a distinctive haramayn school of thought, ${ }^{52}$ presumably, because of the interconnected heterogeneous nature of the "academic communities" of Mecca and Medina, which remained always open to newcomers, who were young men "seeking religious knowledge" and mature scholars. However, the members of these scholarly communities were well informed about intellectual accomplishments, qualifications and reputation of each other and united to some extent by common academic interests. Their birthplaces and areas of early study ranged

${ }^{50}$ Ibid, Vol. 3. p. 414-417.

${ }^{51}$ Al-Jabarti, 'Aja'ib, Vol.1. p. 65-72, 84-86, 89, 161, 190; Al-Jabarti, History of Egypt, Vol.1.p. 107-119, 137-142, 146, 263, 310

52 D. Waines, An Introduction to Islam, p. 204. 
from India and Iran to Algiers and Morocco, although the most common place where they went for further education was Egypt. ${ }^{53}$

A special role in setting up cultural and religious contacts within the Muslim World was played by the adherents of the mystical Islamic tradition, tasawwuf. Many Sufis were widely recognized for their extensive missionary activity in dar al-Islam and their efforts led to reinforcement of ties between the renowned Muslim cultural and religious centers and remote parts of the Islamic ecumene.

The Sufi missionaries were extremely active in the Ottoman Egypt and demonstrated an energetic and dynamic style of interacting with proselytes.

"We should not ignore the psychological aspect of the peregrination problem. As an American researcher Karl K. Barbir rightly noticed, "geographical mobility... was also often complemented by psychic mobility, the transformation of the individual during the actual process of travel... the hajj and Sufism were the means by which Muslims moved from the localized to the cosmopolitan". ${ }^{54}$

As we know, the Sufi path (tariqa) was very long and complicated. It presupposed the guidance of a spiritual mentor in whose hands "his follower had to behave like a corpse in the hands of a corpse washer." Without a teacher it was impossible to attain spiritual perfection, since, according to a famous Sufi aphorism, "for whoever has no teacher, Satan is the mentor." In general Sufism turned to one of the basic forms of Islamic practice. Its organizational forms, shaped for centuries, and effective system of relations between murshids, who teach the Sufi Path - tariqa, and murids (aspirants, or novices) served for the sake of consolidation of the disintegrated Muslim World. The considerable growing of the social role of Islamic mysticism supports the idea that the Islamic history of the eighteenth century means something more than just the gloomy epilogue of the Islamic medieval glory.

${ }^{53}$ J. Voll, "Muhammad Hayya al-Sindi and Muhammad Ibn Abd al-Wahhab: An Analysis of an Intellectual Group in Eighteenth-Century Madina" in Bulletin of the School of Oriental and African Studies, vol. 38, pt. 1, 1975. p. 34

${ }^{54}$ K.Barbir, "The Formation of an Eighteenth Century Sufi: Taha al-Kurdi (17231800)" in Les actes du III symposium d'études Ottomans sur la vie intellectuelle dans les provinces arabes à l'époque ottomane (tome 3), Revue d'Histoire Maghrébine, 59-60, 1990. p. 41, 44 
Sufi wanderings were aimed not only at attainment of spiritual perfection and individual piety, but also at spreading of mystical beliefs and practices and attraction of new murids (disciples). They included obligatory visits to the various sacred places - tombs, shrines and cemeteries, religious and educational centers - qawiyas, takiyas, mosques, madrasas, etc., meetings with the educated and saintly men, who devoted themselves to the Sufi path.

An eminent Syrian traveler 'Abd al-Ghāni al-Nabulsí (16411731), who visited Egypt at the end of the seventeenth century, served as a bright example of Muslim scholar, known by his devotion to the Islamic mystical tradition. In Cairo he was hosted by the leading 'ulama' of al-Azhar, where his lecture on tasawwuf was greeted with an unprecedented enthusiasm. ${ }^{55}$

Siyaha - the wanderings became the meaning of life for an outstanding 'alim-Sufi 'Abd al-Rahmān al-Husayni al-'Aydarus al-Tarimi $(1722-1778)^{56}$, whose famous family lived in the South Arabia. He traveled throughout his life and, as al+Jabarti wrote, put away his "crook of a wanderer" only for short periods of time. He spent 10 years in India, performed bajj 17 times, went to many Syrian towns, Istanbul and Cyprus, was well acquainted with Hijaz, Yemen and different parts of Egypt (he undertook 6 journeys to Sa'id - the Upper Egypt and 8 to Damietta).

In places he visited shaykh al-'Aydarus prayed near sacred tombs and sanctuaries, met numerous men of wisdom and quickly gained a recognition "both in the East, and in the West" Many people - noble and common, rich and poor alike - became Sufis under his spiritual guidance. During his occasional returns to Egypt his residence in Cairo was always overcrowded by visitors from different Muslim lands, who desired to become his aspirants. It is interesting to note that shaykh al-'Aydarus possessed a unique $i j a z a$ (certificate), which enabled him to ordain people into all Sufi turuq.

55 'Abd al-Ghani al-Nabulsi, Al-Hagiqa wa' L-Majāe friblat Bitad ah-Sbam wa Misr wa't-Hijā̃ (Cairo, 1986), p. 102, 105-106, 113 nownge istime-ponto is

${ }^{56}$ His biography see, al-Jabarti, 'Ajä'ib, Vol. 2. p. $27-34$ a

${ }^{57}$ Ibid, p. 29 
A devoted Egyptian Sufi, active propagandist of the mystical values 'Ali ibn 'Umar al-Qinawi (d. 1784) ${ }^{58}$ dedicated twenty long years of his life to wanderings. The amazing routs of his journeys passed through towns and villages of Hijaz, Surat, Basra, Baghdad, Khorasan, Kabul, Kandagar, Ceylon, Benares, Java, etc., where, according to the chronicle's data, he was conducting $d b i k r^{59}$ meetings and acquired a great reputation as a tireless propagator of the tariqa khalwatiya. 'Ali al-Qinawi managed to achieve a distinguished success in Yemen, where he initiated to his tariqa a large group of the inhabitants of Zabid and many Zaydits from mountainous areas of Yemen.

The social mobility made a strong impact on the development of local mystical movements and formation of the saints' cults. I should like to point out in this respect the circumstances of the emergence of the Algerian Sufi brotherhood rahmanniya in the last quarter of the eighteenth century.

Before succeeding on a missionary field in Maghrib, its founder - the Berber shaykh Muhammad ibn 'Abd ar-Rahmān (d. 1793/4) (0 $^{60}$ spent almost three decades far from his native Kabilia in Cairo and on the borders of dar al-Islam. His advanced studies of judicial and mystical sciences in al-Azhar and successful missionary activity in the Eastern Sudan allowed him to join and become a leading figure of the prestigious community of 'ulama'-erudites and "Sufi establishment" in the Arab East. ${ }^{61}$

In such a way tasamnuf connected destinies of Maghrib and Mashriq. The refined Sufi doctrines, cultivated in Azhari intellectual community, were implanted into the Maghribi society, where they came into close contact with local traditional cults.

In conclusion I would like to state the followings. Rich historical data of the Egyptian-Ottoman chronicles and biographical

${ }^{58}$ Ibid, p. $89-90$

${ }^{59}$ Dhikr - the basic liturgical element of Sufi religious practice; it means the glorifying of Allah with certain fixed phrases repeated in a ritual order.

${ }^{60}$ Makhlūf, Shajarät al-Nür al-Zäkìa, p. 372, 1485

${ }^{61}$ Clancy-Smith, "Between Cairo and the Algerian Kabylia: the Rahmaniyya tariqa, 1715-1800" in Muslim Travellers. Pilgrimage, Migration and the Political Imagination, (London, 1990), p. 200-213 
compendiums allows us to affirm that the argument in favor of the intellectual split is hardly applicable to the Arab Muslim World of the eighteenth century. On the contrary, a free migration of ideas was witnessed. Some of these ideas were confronted with the lack of understanding, other found a lively response.

There was a productive intellectual interchange promoted mainly by 'ulam' ' and 'ulama' were guided by cosmopolitan state of their mind (let us remember, that the founder of Islam once uttered "The entire world is a mosque') and prophesized a cult of knowledge (let me recall the well-known saying of the Prophet Muhammad "The ink of the scholar is more precious than the blood of the martyr"). 